\title{
WATER REQUIERMENT OF SOME PEA CULTIVARS PLANTED AT DIFFRANT SOWING DATES UNDER DRIP IRRIGATION SYSTEM \\ 1- Plant growth and yield \\ Dawa, Kawsar. K..; A.H. Amer ${ }^{* *}$ and M.M. Helmy ${ }^{\star *}$ \\ "Vegt.and Ornamental Dept., Fac. Of Agri., Mansoura, Univ. \\ ${ }^{*}$ Veg.Res- Dept., Hort.Inst.,Agric.Res.Center.
}

\begin{abstract}
Two field experiments were carried out during winter season of 2005-2006 and 2006-2007, in EL- Kassasien Horticulture Research Station, Ismailia Governorate. It aimed to study the effect of three irrigation water quantities $(800,1000$ and 1200 $\mathrm{m}^{3} / \mathrm{fed}$.) combined with three sowing dates $\left(20^{\text {th }}\right.$ Sep., $10^{\text {th }}$ Oct. and $1^{\text {st }}$ Nov.) on two cultivars (Victory freezer and Lincoln) of pea (Pisum sativum L.) grown under sandy soil condition using drip irrigation system. The result indicated that increasing water quantity up to $1200 \mathrm{~m}^{3} / \mathrm{fed}$. led to a significant increase of plant growth (plant height, number of branches, leaves per plant and dry weight ) and yield and its components (number of seeds per pod, weight of 100 seeds, net ratio and Green pod yield per fed.).Sowing pea plants on $10^{\text {th }}$ Oct gave the highest value of plant height, number of branches and leaves per plant, dry weight of branches and leaves per plant and yield and its components. Victory freezer cultivar recorded the highest value of plant height, number of branches and leaves per plant, dry weight of branches and leaves per plant and yield and it components. Sowing Victory freezer cultivar on $10^{\text {th }}$ Oct. with application of $1200 \mathrm{~m}^{3} / \mathrm{fed}$.was the best interaction treatment for increasing plant height, number of branches and leaves per plant, dry weight of branches and leaves per plant and yield and its components.
\end{abstract}

\section{INTRODUCTION}

Pea (Pisum sativum L.) is a very popular vegetable crop and considered one of the most important legume crops in Egypt for local consumption and exportation. This crop is widely used as a source of protein in human diets due to its high content of protein, ascorbic acid, carbohydrates, balanced amino acids composition and good digestibility. In general, this crop gives high yield and ensures high profits, especially when cultivated for green pods. Therefore, it occupies a prominent position among other legumes in the Egyptian agriculture.

Many investigators reported that increasing irrigation rates increased plant height, number of branches and leaves per plant, dry weight of branches and leaves per plant and yield and its components (White et al., 1982; Prasad et al., 1987; Nour,1999) on pea (Sawan et al.,2002) on sugar pea, (Ismail, 2000, 2004)on snap been and (Abd El-Ati ,2000, Nour, 2005, EL-Tantawy and EL-Beik, 2007; Nour et al. ,2007) on cowpea. Sowing dates have a considerable effect on world agriculture. Unsuitable sowing dates resulted in reducing plant growth and productivity of pea plants, as mentioned by many investigations. Khalil (1990) found that planting date (Oct.1 $1^{\text {st }}$ ) gave higher values of plant growth and yield than earlier $\left(S e p t .15^{\text {th }}\right)$ or later 
planting date (Oct.15 $\left.5^{\text {th }}\right)$. In the same line El-Gamiely et al., (1998) found that Nov. $15^{\text {th }}$ sowing date significantly increased plant growth and yield of pea

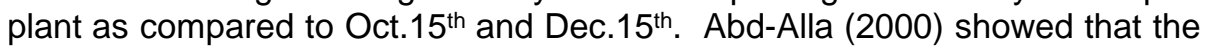
delay of sowing date from Sept. $1^{\text {st }}$ to Oct. $1^{\text {st }}$ increased plant growth and yield of pea plants. Shoker (2000) indicated that planting peas on $15^{\text {th }}$ Oct. increased the plant growth and yield. On the other hand; the lowest values of all characteristics were obtained when planting was at Dec. In the same line, Mansour (2006) showed that sowing peas on $15^{\text {th }}$ Oct. gave the maximum values of plant growth and yield as compared to other sowing date treatments (15 ${ }^{\text {th }}$ Sep. and $15^{\text {th }}$ Nov.).

\section{MATERAILS AND METHODS}

Two field experiments were carried out during winter season of 2005-2006 and 2006-2007 in EL- Kassasien Horticulture Research Station, Ismailia Governorate. It aimed to study the effect of water quantity combined with sowing date on two cultivars of pea (Pisum sativum L.) grown under sandy soil condition using drip irrigation system. Soil samples were taken from 25 $\mathrm{cm}$ soil surface. The physical and chemical properties of the experimental soil are presented in Table (1).

Table (1): The physical and chemical properties of the experimental soil.

\begin{tabular}{|c|c|c|}
\hline Physical properties & $\begin{array}{c}\text { First season } \\
(\mathbf{2 0 0 5 - 2 0 0 6 )}\end{array}$ & $\begin{array}{c}\text { Second season } \\
(\mathbf{2 0 0 6 - 2 0 0 7 )}\end{array}$ \\
\hline Sand (\%) & $88 . .24$ & 83.0 \\
\hline Silt (\%) & 4.25 & 13.0 \\
\hline Clay (\%) & 7.51 & 3.32 \\
\hline O.M (\%) & 0.44 & 0.68 \\
\hline F.C. (\%) & 11.21 & 7.7 \\
\hline W.P. (\%) & 2.24 & 2.8 \\
\hline Texture & sandy & sandy \\
\hline Chemical properties & \multicolumn{2}{|c|}{7.9} \\
\hline pH & 8.1 & 1.66 \\
\hline E.C. (mmohs/cm) & 1.78 & 2.50 \\
\hline HCO3- & 2.00 & 8.00 \\
\hline Cl- & 7.00 & 7.46 \\
\hline SO4-- & 9.48 & 4.68 \\
\hline Ca++ & 4.56 & 2.04 \\
\hline Mg++ & 2.00 & 6.48 \\
\hline Na+ & 7.16 & 0.58 \\
\hline K+ & .70 & 1.23 \\
\hline Available N (ppm) & 1.30 & 1.99 \\
\hline Available P $(\mathrm{ppm})$ & 2.00 & 5.19 \\
\hline Available K (ppm) & 4.94 & \\
\hline 1-O.M.: Organic matter & 2- FC: Field capacity & \multicolumn{1}{|c|}{} \\
3- WP: Wilting point & 4- E.C: Electric conductivity & \\
\hline
\end{tabular}

Local meteorological data at El-Kassasin region during winter season of 2005-2006and2006-2007 were given in Table (2). 
Table (2): the monthly air temperature and relative humidity during winter season of 2005-2006and2006-2007.

\begin{tabular}{|c|c|c|c|c|c|c|c|c|}
\hline \multirow{3}{*}{$\begin{array}{l}\text { season } \\
\text { Month }\end{array}$} & \multicolumn{4}{|c|}{$(2005-2006)$} & \multicolumn{4}{|c|}{$(2006-2007)$} \\
\hline & \multicolumn{3}{|c|}{ Temperature( $\left.{ }^{\circ} \mathrm{C}\right)$} & \multirow{2}{*}{ RH\% } & \multicolumn{3}{|c|}{ Temperature( $\left.{ }^{\circ} \mathrm{c}\right)$} & \multirow{2}{*}{ RH\% } \\
\hline & Max. & Min. & Mean & & Max. & Min. & Mean & \\
\hline Sep. & 32.9 & 22.03 & 27.25 & 52.99 & 34.18 & 23.22 & 28.80 & 53.16 \\
\hline Oct. & 29.32 & 20.6 & 24.72 & & 31.33 & 19.8 & & 60.75 \\
\hline Nov. & 22.07 & 14.52 & 18.21 & 56.67 & 23.51 & 14.87 & 18.71 & 61.78 \\
\hline Dec. & 20.15 & 12.92 & 16.64 & 60.10 & 18.23 & 9.85 & 14.44 & 60.12 \\
\hline Jan. & 18.94 & 9.92 & 14.89 & 60.41 & 18.76 & 9.75 & 14.52 & 59.07 \\
\hline Feb. & 20.18 & 9.82 & 15.58 & 59.95 & 20.81 & 9.80 & 15.96 & 58.30 \\
\hline Mar. & 24.77 & 13.19 & 18.87 & 55.82 & 25.11 & 14.05 & 20.25 & 53.75 \\
\hline Apr. & 28.11 & 16.36 & 22.39 & 50.68 & 23.34 & 12.67 & 17.97 & 55.34 \\
\hline
\end{tabular}

1-Layout of the experiment and treatments:

The experiment included 18 treatments, which were combination between irrigation water quantities, three sowing dates and two cultivars of peas as follows:

A. Irrigation water quantities:

$800 \mathrm{~m}^{3} /$ fed., $1000 \mathrm{~m}^{3} / \mathrm{fed}$. and $1200 \mathrm{~m}^{3} / \mathrm{fed}$.

B. Sowing date:

$20^{\text {th }}$ September, $10^{\text {th }}$ October and $1^{\text {st }}$ November.

C. Cultivars:

Victory freezer and Lincoln.

The treatments were arranged in split-split plot design with three replicates. Irrigation treatments were assigned at random in the main plots, while sub plots were devoted to sowing dates and cultivars were allotted in sub-sub plots. The seeds of cultivars were obtained from Horticultural Research Institute, Agriculture Research Center.

The experimental unit area was $9.6 \mathrm{~m}^{2}$ and it contains 4 dripper lines with $4 \mathrm{~m}$ length for each and $60 \mathrm{~cm}$ width, and the distance between drippers was $25 \mathrm{~cm}$, thus each replicate contains 64 drippers. The seeds (3seeds / hill) were sown after inoculation with root nodules bacteria (Rhizobium leguminosarum) and spaced at $20 \mathrm{~cm}$ on the ridges.

All experimental units received equal amounts of water during germination $\left(50 \mathrm{~m}^{3} / \mathrm{fed}\right)$. The irrigation treatments started 10 days after emergence and were added three days intervals in the morning along plant life. The water was added using water counter. follow:

Data were recorded on plant growth and yield and its components as

\section{A. Plant growth parameters.}

Three plants were taken at random from each plot at 70 days after sowing to evaluate the following vegetative characters. (Plant height, number of branches / plant, number of leaves/plant and Dry weight).

\section{B. Yield and its components.}

Mature green pods were continuously harvested at suitable maturity stages and the following data were calculated. (Number of seeds / pod, Average weight of 100 seeds, Netting percentage and Total yield per fed. Tons / fed). 


\section{RESULTS AND DISCUSSION}

\section{Plant growth.}

1.1 Effect of drip irrigation rates.

Data in Table (3) show the effect of drip irrigation rates on vegetative characters of pea plants during 2005-2006 and 2006-2007 seasons expressed as plant height, number of branches per plant and number of leaves per plant.

It is obvious from such data that plant height, number of branches and leaves per plant were significantly increased with increasing amount of applied irrigation water up to the highest level, i.e., $1200 \mathrm{~m}^{3} / \mathrm{fed}$. in both seasons .

Application of $1200 \mathrm{~m}^{3}$ water / fed. being the most effective treatment and recorded the greatest increments of plant height, number of branches and leaves per plant in both seasons.

The reduction in plant growth under conditions of low soil moisture level( $800 \mathrm{~m}^{3}$ / fed ) as compared with the higher levels ( $1000 \& 1200 \mathrm{~m}^{3}$ ) may be due to that water stress causes losses in tissue water which reduce turger pressure in the cell, thereby inhibition enlargement and division of cells as concluded by Hsiao and Acevedo (1974).Also, the decrease in enlargement and division of cells decrease leaf area and hence the effectiveness of photosynthetic surface (Jain and Misra, 1970).

The obtained results are in harmony with those reported by several workers who indicated the importance of water supply along plant life for increasing plant growth (Nour, 1999; Merghany, 1999; Abd El-Ati, 2000; Ismail 2000, 2004; Amer et al. 2002; Sawan et al., 2002; Nour 2005, ELTantawy and EL-Beik, 2007 and Nour et al., 2007). They concluded that plant height, number of leaves and branches per plant of legume crops were increased with increasing soil moisture content (available soil water) or irrigation rates (water quantity).

\subsection{Effect of sowing dates.}

Data in Table (3) show the effect of sowing date on vegetative characters of pea plants during 2005-2006 and 2006-2007 seasons, expressed as plant height, number of branches per plant and number of leaves per plant.

It is obvious from such data that sowing pea plant on $10^{\text {th }}$ Oct. generally gave the best values of plant height, number of leaves per plant and branches per plant in both seasons. Such results may be due to the suitable temperature range $\left(20-25^{\circ} \mathrm{C}\right)$ as showed in Table (2) during germination and plant growth during the vegetative phase. Moreover, prevailing high temperature during the early sowing date $\left(20^{\text {th }}\right.$ Sept.) pushed the plants to enter the reproductive phase before they complete their normal vegetative growth cycle, resulting in significant reduction in plant height, leaves and branches number. The obtained results are in harmony with those reported by several workers indicated the importance of sowing date along plant life for increasing plant growth (Abd-Alla, 2000, Shoker, 2000, Mansour, 2006) they concluded that plant height, number of leaves and branches per plant of pea plants were increased with sowing seeds at October. 


\subsection{Effect of cultivars.}

Data in Table (3) show the effect of cultivars on vegetative characters of pea plants during 2005-2006 and 2006-2007 seasons, expressed as plant height, number of branches per plant and number of leaves per plant. Such results indicate that the highest values of plant height were recorded with Victory freezer cultivar) in both seasons. While number of branches per plant and number of leaves per plant were not significantly affected by the two cultivars in both growing seasons.

The difference between cultivars may be due to their variations in nutrient use efficiency habits. Another explanation is that the different behavior observed in these characters might reflect the differential expressivity of certain genes during ontogenetic processes, which may interact with the developmental and environmental factors in relation to water relationships, and indicated that genes responsible for the biosynthesis of such characters might be varied in their action (Yarnell, 1962 and Arisha, 1982) on pea plants.

The obtained results agree with those reported by Mohammed and Qandil 1998 and Shoker 2000. on pea plants.

Table (3): Effect of drip irrigation rates, sowing dates, cultivars on vegetative characters during 2005-2006 and 2006-2007 seasons.

\begin{tabular}{|c|c|c|c|c|c|c|}
\hline \multirow{3}{*}{\begin{tabular}{|c|} 
Characters \\
Treatments
\end{tabular}} & \multicolumn{2}{|c|}{ Plant height $(\mathbf{c m})$} & \multicolumn{2}{|c|}{$\begin{array}{c}\text { No. of } \\
\text { Branches / plant }\end{array}$} & \multicolumn{2}{|c|}{$\begin{array}{c}\text { No. of } \\
\text { Leaves / plant } \\
\end{array}$} \\
\hline & & & & son & & \\
\hline & 2005 & 2006 & 2005 & 2006 & 2005 & 2006 \\
\hline \multicolumn{7}{|l|}{ Water quantity $\mathrm{m}^{3} /$ fed. } \\
\hline 800 & 41.030 & 55.989 & 2.461 & 2.622 & 16.139 & 20.711 \\
\hline 1000 & 48.489 & 61.206 & 2.556 & 2.922 & 22.367 & 25.572 \\
\hline 1200 & 66.811 & 69.061 & 3.633 & 4.044 & 25.822 & 36.822 \\
\hline L.S.D 0.05 & 12.374 & 5.510 & 0.715 & 1.222 & 9.317 & 8.472 \\
\hline \multicolumn{7}{|l|}{ Sowing date } \\
\hline $20^{\text {th }}$ Sep. & 46.152 & 3.483 & 16.694 & 55.067 & 3.472 & 27.850 \\
\hline $10^{\text {th }}$ Oct. & 65.417 & 4.622 & 30.756 & 70.378 & 3.817 & 31.828 \\
\hline $1^{\text {st }}$ Nov. & 44.761 & 2.378 & 16.878 & 60.811 & 2.300 & 23.428 \\
\hline L.S.D 0.05 & 9.310 & 0.778 & 4.672 & 6.752 & 0.791 & 7.166 \\
\hline \multicolumn{7}{|l|}{ Cultivars } \\
\hline Vic. & 51.379 & 2.978 & 22.293 & 63.530 & 3.270 & 27.570 \\
\hline Lin. & 46.433 & 2.789 & 20.593 & 60.641 & 3.122 & 27.833 \\
\hline L.S.D 0.05 & 2.447 & N.S & N.S & 2.484 & N.S & N.S \\
\hline
\end{tabular}

Vic.: Victory freezer.

Lin.: Lincoln.

\subsection{Effect of interaction}

Concerning the effect of interaction between drip irrigation rates and sowing dates on vegetative characters of pea plants during 2005-2006 and 2006-2007 seasons in Table (4). It is evident that interaction between drip irrigation rates and sowing dates had a significant effect on number of branches and leaves per plant in both growing seasons except number of branches in the first season. The highest values of number of branches and leaves per plant were recorded when seeds of pea were sown on $10^{\text {th }}$ Oct. and irrigated with $1200 \mathrm{~m}^{3} / \mathrm{fed}$. 
Dawa, Kawsar. K. et al.

Generally, increasing plant growth in early sowing dates with adding highest level of irrigation water decreased the unsuitable effects of high temperature at the early sowing date on plant growth, while at medium sowing date, the plant responded better to the moderate levels of irrigation water and this might be attributed to the low temperature and low solar radiation in this period than the earlier sowing. These results are in agreement with those reported by Nour, 1999 on pea plants.

Results in Table (4) show the effect of interaction between drip irrigation rates and cultivars on vegetative characters of pea plants.

Such results indicate that interaction between drip irrigation rates and cultivars had a significant effect on all the vegetative characters in first season except number of leaves, while the second season had no significant effects were obtained on all vegetative characters except number of leaves.

The highest values of plant height were recorded when victory freezer plants were irrigated with $1200 \mathrm{~m}^{3} /$ fed., while the highest values of number of branches and leaves per plant were recorded when Lincoln plants were irrigated with $1200 \mathrm{~m}^{3} /$ fed. These results are in agreement with those reported by (Ismail, 2000, Sawan et al., 2001, Nour, 2005) on legume crops.

Regarding, the effect of interaction between sowing dates and cultivars on vegetative characters of pea plants not significant effect on all vegetative characters in both seasons were detected except number of branches in the first season as shown in Table (4).

Concerning the effect of interaction among drip irrigation rates, sowing dates and cultivars on vegetative characters, in Table (5),the results showed that all interaction treatments did not significantly affect vegetative characters of pea plants under study.

\section{Dry weight}

\subsection{Effect of drip irrigation rates.}

The effect of drip irrigation rates on dry weight of different organs of pea plants during 2005-2006 and 2006-2007 seasons is presented in Table (6). It is obvious from such data that dry weight of different organs of pea plants was significantly affected by different amounts of irrigation water.

Increasing amount of irrigation water significantly increased dry weight of different plant organs of pea plants, i.e., branches and leaves in both seasons. Application of $1200 \mathrm{~m}^{3} /$ fed. being the most effective treatment and recorded the greatest increments of branches and leaves dry weights in both seasons. 
Table (4): Effect of interaction between drip irrigation rates and sowing dates, drip irrigation rates and cultivars and interaction between sowing dates and cultivars on vegetative characters during 2005-2006 and 2006-2007 seasons.

\begin{tabular}{|c|c|c|c|c|c|c|c|}
\hline \multicolumn{2}{|c|}{\begin{tabular}{|l} 
Drip irrigation rates and \\
Treatments
\end{tabular}} & \multicolumn{2}{|c|}{$\begin{array}{l}\text { Plant height } \\
\text { (cm) }\end{array}$} & \multicolumn{2}{|c|}{$\begin{array}{c}\text { No. of } \\
\text { Branches / plant }\end{array}$} & \multicolumn{2}{|c|}{$\begin{array}{c}\text { No. of } \\
\text { Leaves / plant }\end{array}$} \\
\hline \multirow{2}{*}{$\begin{array}{l}\text { Water } \\
\text { quantity } \\
\left(\mathrm{m}^{3} / \mathrm{fed}\right) \\
\end{array}$} & \multirow[b]{2}{*}{ Sowing date } & \multicolumn{6}{|c|}{ Season } \\
\hline & & 2005 & 2006 & 2005 & 2006 & 2005 & 2006 \\
\hline \multirow{3}{*}{800} & $20^{\text {th }}$ Sep. & 41.357 & 47.483 & 2.933 & 2.633 & 15.300 & 21.717 \\
\hline & $10^{\text {th }}$ Oct. & 45.983 & 62.283 & 33 & & 83 & 367 \\
\hline & $1^{\text {stNov. }}$ & 35.75 & 58.200 & 2.317 & & 33 & 19 \\
\hline \multirow{3}{*}{1000} & $20^{\text {th }}$ Sep. & 44.400 & 55.683 & 3.367 & & 50 & \\
\hline & $10^{\text {th }}$ Oct. & 55.533 & 70 & 4.900 & & 00 & \\
\hline & $1^{\text {st Nov. }}$ & 45.533 & 57. & 1.983 & & 50 & 00 \\
\hline \multirow{3}{*}{1200} & $20^{\text {th }}$ Sep. & 52.700 & 62.033 & 4.150 & 4. & 33 & 650 \\
\hline & $10^{\text {th }}$ Oct. & 61.400 & 78.233 & 5.633 & 4. & 83 & 47.683 \\
\hline & $1^{\text {st }}$ Nov. & 53.000 & 66.917 & 33 & & 18 & 33 \\
\hline \multicolumn{2}{|c|}{ L.S.D at 0.05} & N.S & N.S & N.S & 1.119 & 6.607 & 10.135 \\
\hline \multicolumn{8}{|c|}{ Drip irrigation rates and cultivars. } \\
\hline \multirow{2}{*}{$\begin{array}{l}\text { Water } \\
\text { quantity } \\
\text { (m³/fed.) }\end{array}$} & & \multicolumn{6}{|c|}{ Season } \\
\hline & Cultivars & 2005 & 2006 & 2005 & 2006 & 2005 & 2006 \\
\hline \multirow{5}{*}{$\begin{array}{r}800 \\
1000 \\
1200 \\
\end{array}$} & $\begin{array}{l}\text { Vic. } \\
\text { Lin. }\end{array}$ & $\begin{array}{l}42.449 \\
39611\end{array}$ & $\begin{array}{l}59.189 \\
52789\end{array}$ & $\begin{array}{l}2.822 \\
2.900\end{array}$ & & 16.467 & 21.767 \\
\hline & Vic. & 50.411 & $\begin{array}{l}52.189 \\
60.622\end{array}$ & 3.444 & 2. & $\begin{array}{l}15 \\
23\end{array}$ & $\begin{array}{l}056 \\
567\end{array}$ \\
\hline & Lin. & 46.567 & 61.789 & 3.389 & 2. & 20 & 25.578 \\
\hline & $\begin{array}{l}\text { Vic. } \\
\text { Lin. }\end{array}$ & $\begin{array}{l}58.278 \\
53.122\end{array}$ & $\begin{array}{l}70.778 \\
67.344\end{array}$ & $\begin{array}{l}4.200 \\
4211\end{array}$ & $\begin{array}{l}4.378 \\
3.711\end{array}$ & $\begin{array}{l}26.478 \\
25.167\end{array}$ & $\begin{array}{l}35.378 \\
38.267\end{array}$ \\
\hline & at 0.05 & 8.332 & N.S & 1.076 & N.S & N.S & 3.657 \\
\hline \multicolumn{8}{|c|}{ Sowing dates and cultivars. } \\
\hline \multirow{2}{*}{$\begin{array}{c}\text { Sowing } \\
\text { date }\end{array}$} & Cu & \multicolumn{6}{|c|}{ Season } \\
\hline & Is & 2005 & & 2005 & & 2005 & 2006 \\
\hline \multirow{4}{*}{$\begin{array}{l}20^{\text {th }} \text { Sep. } \\
10^{\text {th }} \text { Oct. } \\
1^{\text {st Nov. }}\end{array}$} & $\begin{array}{l}\text { Vic. } \\
\text { Lin. }\end{array}$ & $\begin{array}{l}47.938 \\
44.367\end{array}$ & $\begin{array}{l}55.567 \\
54.567\end{array}$ & $\begin{array}{l}3.022 \\
3.644\end{array}$ & $\begin{array}{l}3.789 \\
3.156\end{array}$ & $\begin{array}{l}17.156 \\
16.233\end{array}$ & $\begin{array}{l}28.944 \\
26.756\end{array}$ \\
\hline & Vic. & 55.722 & 72.344 & 3.333 & & 32.244 & 31.311 \\
\hline & Lin. & 52.889 & & & & 29 & \\
\hline & Vic. & 47.478 & & & & 17. & 22.456 \\
\hline \multicolumn{2}{|c|}{ L.S.D at 0.05} & N.S & N.S & 1.076 & N.S & N.S & N.S \\
\hline
\end{tabular}

Vic.: Victory freezer.

Lin.: Lincoln. 
Dawa, Kawsar. K. et al.

Table (5): Effect of interaction among drip irrigation rates, sowing dates and cultivars on vegetative characters during 2005-2006 and 2006-2007 seasons.

\begin{tabular}{|c|c|c|c|c|c|c|c|c|}
\hline \multicolumn{3}{|c|}{$\begin{array}{ll}\text { Treatments } & \text { Characters }\end{array}$} & \multicolumn{2}{|c|}{$\begin{array}{l}\text { Plant height } \\
\text { (cm) }\end{array}$} & \multicolumn{2}{|c|}{$\begin{array}{c}\text { No. of } \\
\text { branches/ plant }\end{array}$} & \multicolumn{2}{|c|}{$\begin{array}{c}\text { No. of } \\
\text { Leaves / plant }\end{array}$} \\
\hline \multirow{2}{*}{$\begin{array}{c}\text { Water } \\
\text { quantity } \\
\left(\mathrm{m}^{3} / \mathrm{fed}\right)\end{array}$} & \multirow{2}{*}{ Sowing $c$} & \multirow{2}{*}{ Cultivars } & \multicolumn{6}{|c|}{ Season } \\
\hline & & & 2005 & 2006 & 2005 & 2006 & 2005 & 2006 \\
\hline \multirow{4}{*}{800} & & Vic. & 41.613 & 50.000 & 2.433 & 2.533 & 15.333 & 23.133 \\
\hline & & Lin. & 41.100 & 44.967 & 3.433 & 2.733 & 15.267 & 20.300 \\
\hline & & Vic. & 48.100 & 66.500 & 3.400 & 2.867 & 18.200 & 21.067 \\
\hline & & Lin. & 43.867 & 58.067 & 3.267 & 3.767 & 17.967 & 20.667 \\
\hline \multirow{6}{*}{1000} & & Vic. & 37.633 & 61.067 & 2.633 & 1.967 & 15.867 & 21.100 \\
\hline & & Lin. & 33.867 & 55.333 & 2.000 & 1.867 & 14.200 & 18.000 \\
\hline & & Vic. & 46.933 & 53.733 & 2.867 & 3.300 & 18.400 & 29.500 \\
\hline & & Lin. & 41.867 & 57.633 & 3.867 & 3.300 & 16.100 & 26.867 \\
\hline & 10 & Vic. & 58.667 & 69.800 & 5.367 & 3.200 & 34.667 & 26.667 \\
\hline & CL. & Lin. & 52.400 & 71.433 & 4.433 & 3.100 & 30.533 & 27.200 \\
\hline \multirow{8}{*}{1200} & \multirow{2}{*}{$1^{\text {st }}$ Nov. } & Vic. & 45.633 & 58.333 & 2.100 & 2.433 & 18.733 & 20.533 \\
\hline & & Lin. & 45.433 & 56.300 & 1.867 & 2.200 & 15.767 & 22.667 \\
\hline & \multirow{2}{*}{$20^{\text {th }}$ Sep. } & Vic. & 55.267 & 62.967 & 3.767 & 5.533 & 17.733 & 34.200 \\
\hline & & Lin. & 50.133 & 61.100 & 4.533 & 3.433 & 17.333 & 33.100 \\
\hline & \multirow{2}{*}{$10^{\text {th }}$ Oct. } & Vic. & 60.400 & 80.733 & 5.833 & 5.100 & 43.867 & 46.200 \\
\hline & & Lin. & 62.400 & 75.733 & 5.433 & 4.867 & 39.300 & 49.167 \\
\hline & \multirow{2}{*}{$1^{\text {st }}$ Nov. } & Vic. & 59.167 & 68.633 & 3.000 & 2.500 & 17.833 & 25.733 \\
\hline & & Lin. & 46.833 & 65.200 & 2.667 & 2.833 & 18.867 & 32.533 \\
\hline \multicolumn{3}{|c|}{ L.S.D 0.05} & N.S & N.S & N.S & N.S & N.S & N.S \\
\hline
\end{tabular}

Vic.: Victory freezer. Lin.: Lincoln.

The favorable effect of water supply on dry weight of pea plant may be attributed to the favorable soil moisture condition which led to an increase in plant growth which might contribute much for the superiority in dry weight. Unfavorable effect of drought on dry matter production may be due to the reduction in the uptake of nutrition elements thus causing a disturbance in the physiological processes needed for plant growth (Slatyer, 1969) or to the reduction in leaf area and photosynthetic rate (Fisher and Hogan, 1965). and a reduction in $\mathrm{CO}_{2}$ assimilation due to stomata closure (Hsiao and Acevedo, 1974). The photosynthetic efficiency in Phaseolus vulgaris began to decrease with a slight deficit in the soil moisture content due to the decrease in the mesophyll photosynthetic activity at high xylem water potential (Gawish 1992) and this in turn might explain the reduction in dry matter of pea plants with decreasing water irrigation under this study. The obtained results are in harmony with those reported by several workers (Nour, 1999; Ismail, 2000, 2004; Amer et al,. 2002 a\&b, Nour, 2005, El-Tantawy and El-Beik 2007, Nour et al., 2007) on legume crops.

2.2. Effect of sowing dates.

The effect of sowing date on dry weight of different organs of pea plants 2005-2006 and 2006-2007 seasons is presented in Table (6).

It is obvious from such data that dry weights of different organs of pea plants are significantly affected by sowing dates in both seasons .Pea sowing on $10^{\text {th }}$ Oct. recorded the greatest increments of branches dry weight and leaves dry weight in both seasons. 
It is well known the suitable temperature range to pars thrive $\left(20-25^{\circ} \mathrm{C}\right)$ that prevailing during October sowing date (Table 3). The higher temperature and solar radiation in sandy soil may be affect photosynthetic activity and this in turn affect dry matter accumulation .Any factor affect plant metabolism may affect plant growth and this in turn affect photosynthetic surface and thereby dry matter accumulation. (Jain and Misrs, 1970).

The obtained results are in harmony with those reported by Khalil (1990), Shoker (2000) and Mansour (2006) on pea plants.

\section{3. Effect of cultivars.}

The effect of cultivars on dry weight of different organs of pea plants during 2005-2006 and 2006-2007 seasons is presented in Table (6).It is obvious from such data that dry weight of different organs of pea plants was significantly affected by cultivars in the first season only.

The highest values of dry weight of branches and leaves were recorded with sowing $\mathrm{cv}$. Victory freezer.

Simler results were obtained with those reported by (Mohammed and El-Kabany, 1999, Ismai, 2000, Shoker, 2000, Amar et al., 2002 b, ElAssiouty, 2004 and Nour 2005 on legume crops.

\subsection{Effect of interaction}

Concerning the effect of interaction between drip irrigation rates and sowing dates on dry weight of pea plants as shown in Table (7), it is evident that no significant effect on dry weight of branches and leaves in both growing seasons except dry weight of leaves in the second season.

Generally, the obtained results indicated that planting peas seeds on $10^{\text {th }}$ Oct. gave high values of dry weights with all applied water quantities.

Table (6): Effect of drip irrigation rates, sowing dates and cultivars on dry weight during 2005-2006 and 2006-2007 seasons.

\begin{tabular}{|c|c|c|c|c|}
\hline Characters & \multicolumn{2}{|c|}{$\begin{array}{c}\text { D.W. of branches/ plant } \\
\text { (gm) }\end{array}$} & \multicolumn{2}{|c|}{$\begin{array}{c}\text { D.W. of leaves/plant } \\
\text { (gm) }\end{array}$} \\
\hline \multirow{2}{*}{ Treatment } & \multicolumn{4}{|c|}{ Season } \\
\hline & 2005 & 2006 & 2005 & 2006 \\
\hline \multicolumn{5}{|l|}{ Water quantity $\mathrm{m}^{3} /$ fed. } \\
\hline 800 & 2.276 & 2.917 & 2.953 & 4.136 \\
\hline 1000 & 2.384 & 3.280 & 4.038 & 5.684 \\
\hline 1200 & 3.182 & 5.035 & 5.494 & 7.688 \\
\hline L.S.D 0.05 & 0.722 & 2.706 & 1.856 & 1.190 \\
\hline \multicolumn{5}{|l|}{ Sowing date } \\
\hline $20^{\text {th }}$ Sep. & 2.132 & 4.085 & 3.276 & 5.513 \\
\hline $10^{\text {th }}$ Oct. & 3.290 & 4.369 & 5.251 & 7.318 \\
\hline $1^{\text {st }}$ Nov. & 2.419 & 2.777 & 3.958 & 4.677 \\
\hline L.S.D 0.05 & 0.606 & 1.899 & 1.311 & .703 \\
\hline \multicolumn{5}{|l|}{ Cultivars } \\
\hline Vic. & 2.737 & 3.723 & 4.304 & 5.933 \\
\hline Lin. & 2.490 & 3.765 & 4.019 & 5.738 \\
\hline L.S.D 0.05 & 0.162 & N.S & 0.046 & N.S \\
\hline
\end{tabular}

Vic.: Victory freezer.

Lin.: Lincoln. 
Dawa, Kawsar. K. et al.

Table(7): Effect of interaction between drip irrigation rates and sowing dates, drip irrigation rates and cultivars and interaction between sowing dates and cultivars on dry weight during 2005-2006 and 2006-2007 seasons.

Drip irrigation rates and sowing dates.

\begin{tabular}{|c|c|c|c|c|c|}
\hline \multirow{3}{*}{\begin{tabular}{|c|} 
Treatments \\
Water \\
quantity \\
(m³/fed.)
\end{tabular}} & \multirow{3}{*}{\begin{tabular}{|c|} 
Characters \\
$\begin{array}{c}\text { Sowing } \\
\text { date }\end{array}$ \\
\end{tabular}} & \multicolumn{2}{|c|}{$\begin{array}{c}\text { D.W. of branches/ plant } \\
(\mathrm{gm})\end{array}$} & \multicolumn{2}{|c|}{$\begin{array}{l}\text { D.W. of leaves/ plant } \\
\text { (gm) }\end{array}$} \\
\hline & & \multicolumn{4}{|c|}{ Season } \\
\hline & & 2005 & 2006 & 2005 & 2006 \\
\hline \multirow{3}{*}{800} & $20^{\text {th }}$ Sep. & 2.010 & 3.227 & 2.348 & 4.225 \\
\hline & $10^{\text {th }}$ Oct. & 2.765 & 3.160 & 3.708 & 4.397 \\
\hline & $1^{\text {st Nov. }}$ & 2.053 & 2.363 & 2.803 & 5.890 \\
\hline \multirow{3}{*}{1000} & $20^{\text {th }}$ Sep. & 1.882 & 3.513 & 3.327 & 5.658 \\
\hline & $10^{\text {th }}$ Oct. & 2.967 & 3.763 & 4.695 & 6.902 \\
\hline & $1^{\text {st Nov. }}$ & 2.303 & 2.563 & 4.093 & 4.260 \\
\hline \multirow{3}{*}{1200} & $20^{\text {th }}$ Sep. & 2.505 & 5.515 & 4.153 & 6.424 \\
\hline & $10^{\text {th }}$ Oct. & 4.138 & 6.185 & 7.350 & 10.654 \\
\hline & $1^{\text {st }}$ Nov. & 2.902 & 3.405 & 4.978 & 5.985 \\
\hline \multicolumn{2}{|c|}{ L.S.D at 0.05} & N.S & N.S & N.S & 1.826 \\
\hline \multicolumn{6}{|c|}{ Drip irrigation rates and cultivars. } \\
\hline \multirow{2}{*}{$\begin{array}{c}\text { Water } \\
\text { quantity } \\
\text { (m³/fed.) }\end{array}$} & \multirow{2}{*}{ Cultivars } & \multicolumn{4}{|c|}{ Season } \\
\hline & & 2005 & 2006 & 2005 & 2006 \\
\hline 800 & $\begin{array}{l}\text { Vic. } \\
\text { Lin }\end{array}$ & $\begin{array}{l}2.388 \\
2.164\end{array}$ & $\begin{array}{l}2.876 \\
2.958\end{array}$ & $\begin{array}{l}2.962 \\
2.944\end{array}$ & $\begin{array}{l}4.087 \\
4.184\end{array}$ \\
\hline \multirow{2}{*}{1000} & Vic. & 2.454 & 3.224 & 4.084 & 5.734 \\
\hline & Lin & 2.313 & 3.336 & 3.992 & 5.633 \\
\hline \multirow{2}{*}{1200} & Vic. & 3.370 & 5.069 & 5.867 & 7.978 \\
\hline & Lin & 2.946 & 5.001 & 5.121 & 7.397 \\
\hline \multicolumn{2}{|c|}{ L.S.D at 0.05} & N.S & N.S & 0.656 & N.S \\
\hline \multicolumn{6}{|c|}{ Sowing dates and cultivars. } \\
\hline \multirow{2}{*}{\multicolumn{2}{|c|}{ Sowing date Cultivars }} & & & & \\
\hline & & 2005 & 2006 & 2005 & 2006 \\
\hline \multirow{2}{*}{$20^{\text {th }}$ Sep. } & Vic. & 2.164 & 4.039 & 3.234 & 5.815 \\
\hline & Lin & 2.100 & 4.131 & 3.318 & 5.211 \\
\hline \multirow{2}{*}{$10^{\text {th }}$ Oct. } & Vic. & 3.517 & 4.329 & 5.598 & 7.378 \\
\hline & Lin & 3.063 & 4.410 & 4.904 & 7.257 \\
\hline \multirow{2}{*}{$1^{\text {st }}$ Nov. } & Vic. & 2.531 & 2.801 & 4.081 & 4.607 \\
\hline & Lin & 2.308 & 2.753 & 3.836 & 4.747 \\
\hline \multicolumn{2}{|c|}{ L.S.D at 0.05} & N.S & N.S & N.S & N.S \\
\hline
\end{tabular}

Vic.: Victory freezer.

Lin.: Lincoln.

The highest values of dry weight of branches and leaves were recorded when pea plants were sown on $\left(10^{\text {th }}\right.$ Oct. and irrigated with $1200 \mathrm{~m}^{3} /$ fed.). The increase in dry matter content with interaction between drip irrigation rates and sowing dates took the same trend of growth attributes and this in turn explain the effect of this interaction on dry matter content of pea plant. The suitable irrigation rate at different sowing dates may be explained 
by the levels of temperature and solar radiation at the different sowing dates in sandy soil.

Results in Table (7) show the effect of interaction between drip irrigation rates and cultivars on dry weight of pea plants. It is evident that no significant effect on dry weight of branches and dry weight of leaves in both growing seasons, except dry weight of leaves in first season only.

Generally, the highest values of dry weight of leaves were recorded with cv. victory freezer were irrigated with $1200 \mathrm{~m}^{3} /$ fed.

The obtained results are in harmony with those reported by Ismail (2000) and Nour (2005) on legume crops.

Results in Table (7) show that the interaction between sowing dates and cultivars did not significantly affected on dry weight of branches and leaves at both season as shown in Table (7).

It is obvious from such data that dry weight of different organs of pea plants were not significantly affected by the interaction among drip irrigation rates, sowing dates and cultivars in both seasons as shown in Table (8)

Table (8): Effect of interaction among drip irrigation rates, sowing dates and cultivars on dry weight during 2005-2006 and 2006-2007 seasons.

\begin{tabular}{|c|c|c|c|c|c|c|}
\hline Treatments & Che & racters & D.W. of br & hes/ $\mathrm{p}$ & W. of le & $\begin{array}{l}\text { es/plant } \\
\text { 1) }\end{array}$ \\
\hline Water & & & & & & \\
\hline $\begin{array}{c}\text { quantity } \\
\text { (m /fed.) }\end{array}$ & owing date & cultivars & 2005 & 2006 & 2005 & 2006 \\
\hline & & Vic. & 2.043 & 2.997 & 2.483 & 4.213 \\
\hline & $20^{\circ \prime}$ sep. & Lin. & 1.977 & 3.457 & 2.213 & 4.237 \\
\hline & & Vic. & 3.063 & 3.063 & 3.773 & 4.443 \\
\hline 800 & 10th Oct. & Lin. & 2.057 & 3.257 & 3.643 & 3.603 \\
\hline & & Vic. & 2.06 & 2.567 & 2.630 & 3.967 \\
\hline & ISt INOV. & Lin. & 2.050 & 2.160 & 2.977 & 3.967 \\
\hline & & Vic. & 1.880 & 3.683 & 3.150 & 5.943 \\
\hline & $20^{\circ \prime}$ Sep. & Lin. & 1.883 & 3.343 & 3.503 & 5.837 \\
\hline & & Vic. & 3.020 & 3.263 & 4.953 & 6.927 \\
\hline 1000 & 10th Oct. & Lin. & 2.913 & 4.263 & 4.437 & 6.877 \\
\hline & & Vic. & 2.463 & 2.727 & 4.150 & 4.333 \\
\hline & Ist Nov. & Lin. & 2.143 & 2.4 & 4.037 & 4.187 \\
\hline & & Vic. & 2.570 & 5.437 & 4.070 & 7.288 \\
\hline & $20^{\text {tn }}$ Sep. & Lin. & 2.440 & 5.593 & 4.237 & 5.560 \\
\hline & & Vic. & 4.467 & 6.660 & 8.067 & 10.763 \\
\hline 1200 & 10th Oct. & Lin. & 3.810 & 5.710 & 6.633 & 10.546 \\
\hline & & Vic. & 3.073 & 3.110 & 5.463 & 5.883 \\
\hline & ISt & Lin. & 2.730 & 3.7 & 4.493 & 6.087 \\
\hline L.S.D at & 0.05 & & N.S & N.S & N.S & N.S \\
\hline
\end{tabular}

Vic.: Victory freezer.

Lin.: Lincoln 
3. Yield and its components.

\subsection{Effect of drip irrigation rates.}

Data in Table (9) show the effect of drip irrigation rates on yield and its components, i.e., number of seeds per pod, weight of 100 seeds, net ratio and green pod yield per fed., of pea plants during 2005-2006 and 2006-2007 seasons.

The results show that there were significant effects on weight of 100 seeds in the second season only and net ratio and green pod yield per fed. in both seasons by applied irrigation water. The maximum values of net ratio in the first season and green pod yield per fed. in both seasons were recorded with $1200 \mathrm{~m}^{3}$ / fed.

Todd (1972) reported that water stress inhibit nitrate reeducates activity. Sangakara (1990) reported that nodulation was optimal when green bean plants were grown at higher soil moisture levels and nodule activity was reduced by moisture stress. Marschner (1995) stated that water stress depress nitrogenous activity, while, Streeter (1993) reported that a decrease in phloem solute import presumably inhibits $\mathrm{N}$ export and $\mathrm{N}_{2}$ fixation by water limitation for xylem export. It could be concluded from these reports that water deficit decrease nodulation, nitrogen's and nitrate reeducate activities and $\mathrm{N}_{2}$ fixation which in turn affect pea yield.

These results coincide with those reported by (Nour, 1999; Merghany, 1999; Ismail, 2000; Amer et al., 2002 a\&b; Sawan et al., 2002; Ismail, 2004; Nour, 2005; EL-Tantawy and EL-Beik, 2007, Nour et al., 2007) on legume crops.

\subsection{Effect of sowing dates.}

Data in Table (9) show the effect of sowing dates on yield and its components, i.e., number of seeds per pod, weight of 100 seeds, net ratio and green pod yield per fed. of pea plants during 2005-2006 and 2006-2007 seasons.

The results indicted that sowing dates had a significant effected on weight of 100 seeds, net ratio and green pod yield per fed. in both seasons.

In addition number of seeds per pod was not affected by sowing dates in both seasons of study. In

general, the greatest average weight of 100 seeds were recorded with $10^{\text {th }}$ Oct. or $1^{\text {st }}$ Nov. while $10^{\text {th }}$ Oct. recorded the maximum values of net ratio and green pod yield per fed. the superiority in net ratio, green pod yield per fed. on $10^{\text {th }}$ Oct. may be attributed to high plant growth parameters as previously in Tables (3) and (6) .

The results are in harmony with those reported by (Khalil, 1990; ElGamiely et al. 1998; Nour, 1999; Abd-Alla, 2000; Shoker, 2000 and Mansour, 2006).

\subsection{Effect of cultivars.}

It is obvious from the data presented in Table (9) that there were significant differences between the two cultivars in weight of 100 seeds in the first season and number of seeds per pod, net ratio and green pod yield per fed. in the second season only. Victory freezer recorded highest values of number of seeds per pod and green pod yield per fed. in the second season. 
The results are in harmony with those reported by (Ismail, 2000, Shoker, 2000, El-Assioty, 2004, Nour, 2005).

\subsection{Effect of interaction.}

Data in Table (10) show the effect of interaction between drip irrigation rates and sowing date on yield and its components, i.e., number of seeds per pod, weight of 100 seeds, net ratio and Green pod yield per fed. of pea plants during 2005-2006 and 2006-2007 seasons.

It is clear from the data that the interaction between drip irrigation rates and sowing date had a significant effect in weight of 100 seeds in the first season only. In general, it could be saying that the best interaction treatment for increasing weight of 100 seeds was the application of $1200 \mathrm{~m}^{3} / \mathrm{fed}$. and sown pea plant on $10^{\text {th }}$ Oct.

It is evident that interaction between drip irrigation rates and cultivars had non significant effects on yield and its components both season as shown in table (10)

Data in table (10) show the effect of interaction between sowing date and cultivars on yield and its components, i.e., number of seeds per pod, weight of 100 seeds, net ratio and green pod yield per fed. of pea plants during 2005-2006 and 2006-2007 seasons.

It is evident that interaction among drip irrigation rates, sowing dates and cultivars had not significant effects yield and its components of pea plants. These results are true in the two growing seasons as shown in Table (11).

Table (9): Effect of drip irrigation rates, sowing dates, cultivars on yield and its components during 2005-2006 and 2006-2007 seasons.

\begin{tabular}{|c|c|c|c|c|c|c|c|c|}
\hline \multirow{3}{*}{ Treatments } & \multicolumn{2}{|c|}{$\begin{array}{c}\text { No. of } \\
\text { seeds/pod }\end{array}$} & \multicolumn{2}{|c|}{$\begin{array}{l}\text { Wt. of } 100 \\
\text { seeds }(\mathrm{gm})\end{array}$} & \multicolumn{2}{|c|}{ Netting\% } & \multicolumn{2}{|c|}{$\begin{array}{l}\text { Green pod yield } \\
\text { tons/fed. }\end{array}$} \\
\hline & \multicolumn{8}{|c|}{ Season } \\
\hline & 2005 & 2006 & 2005 & 2006 & 2005 & 2000 & 005 & 2006 \\
\hline \multicolumn{9}{|c|}{ Water quantity $\mathrm{m}^{3} /$ fed. } \\
\hline 800 & 6.089 & 5.933 & 39.344 & 39.717 & 46.444 & 49.000 & 4.729 & 4.767 \\
\hline 1000 & 6.289 & 5.828 & 41.133 & 36.733 & 48.422 & 50.817 & 5.080 & 5.066 \\
\hline 1200 & 6.389 & 6.222 & 39.483 & 41.289 & 53.072 & 53.383 & 5.180 & 5.209 \\
\hline L.S.D 0.05 & NS & N.S & NS & 3.894 & 5.521 & 3.635 & 0.246 & 0.275 \\
\hline \multicolumn{9}{|c|}{ Sowing date } \\
\hline $20^{\text {th }}$ Sep. & 5.972 & 6.117 & 37.506 & 42.356 & 48.589 & 49.883 & 4.862 & 4.892 \\
\hline $10^{\text {th }}$ Oct. & .494 & 5.961 & 40.144 & 38.239 & 51. & 55.117 & \begin{tabular}{|l|l|}
7.133 \\
\end{tabular} & 5.206 \\
\hline $1^{\text {st }}$ Nov. & 6.300 & 5.906 & 42.311 & 37.144 & 47.917 & 48.200 & 4.994 & 4.945 \\
\hline L.S.D 0.05 & 15 & NS & 4.725 & 2.779 & 3.595 & 4.949 & 0.233 & 0.175 \\
\hline \multicolumn{9}{|c|}{ Cultivars } \\
\hline Vic. & 6.189 & 5.804 & 39.870 & 40.122 & 50.052 & & 5.023 & 5.060 \\
\hline Lin. & 6.322 & 6.185 & 40.104 & 38.370 & 48.574 & 50.241 & 4.970 & 4.969 \\
\hline L.S.D 0.0 & N.S & N.S & N.S & N.S & N.S & 1.123 & N.S & 0.081 \\
\hline
\end{tabular}


Dawa, Kawsar. K. et al.

Table (10): Effect of interaction between drip irrigation rates and sowing dates, drip irrigation rates and cultivars and sowing dates and cultivars on yield and its components during 2005-2006 and 2006-2007 seasons.

Drip irrigation rates and sowing dates.

\begin{tabular}{|c|c|c|c|c|c|c|c|c|c|}
\hline \multirow{3}{*}{\multicolumn{2}{|c|}{\begin{tabular}{|c|} 
Character \\
Treatments \\
$\begin{array}{l}\text { Water } \\
\text { quantity owing dat } \\
\left(\mathrm{m}^{3} / \mathrm{fed}\right)\end{array}$ \\
\end{tabular}}} & \multicolumn{2}{|c|}{$\begin{array}{c}\text { No. of } \\
\text { seeds/pod }\end{array}$} & \multicolumn{2}{|c|}{$\begin{array}{l}\text { Wt. of } 100 \\
\text { seeds(gm) }\end{array}$} & \multicolumn{2}{|c|}{ Netting $\%$} & \multicolumn{2}{|c|}{$\begin{array}{c}\text { Green pod } \\
\text { yield tons/fed }\end{array}$} \\
\hline & & \multicolumn{8}{|c|}{ Season } \\
\hline & & 2005 & 2006 & 2005 & 2006 & 2005 & 2006 & 2005 & 2006 \\
\hline \multirow{3}{*}{800} & $20^{\text {th }}$ Sep. & 6.100 & 5.900 & 37.60 & 43.30 & 46.05 & 48.30 & 4.620 & 6 \\
\hline & $10^{\text {th }}$ Oct. & 6.083 & 6.133 & 41.30 & 38.71 & 47.60 & 51.28 & & \\
\hline & $1^{\text {st Nov. }}$ & 6.083 & 5.767 & 39.13 & 37.13 & 45.68 & & & \\
\hline \multirow{3}{*}{1000} & $20^{\text {th }}$ Sep. & 5.967 & 6.150 & 36.47 & 38.43 & 47.76 & 49.95 & 4.896 & 4.944 \\
\hline & $10^{\text {th }}$ Oct. & 6.783 & 5.667 & 40.17 & 34.46 & 50.20 & 54.18 & 5.197 & 5.256 \\
\hline & Ist Nov. $^{\text {st }}$ & 6.117 & 5.667 & 46.77 & 37.30 & 47.30 & 48.31 & & 4. \\
\hline \multirow{3}{*}{1200} & $20^{\text {th }}$ Sep. & 5.850 & 6.300 & 38.45 & 45.33 & 51. & 51.40 & & 5. \\
\hline & $10^{\text {th }}$ Oct. & 6.617 & 6.083 & 38.96 & 41.53 & 56.50 & 59.88 & & 5.466 \\
\hline & ${ }^{\text {st }}$ Nov. & 6.700 & 6.283 & 41.033 & 37.00 & 50.76 & 48.86 & 06 & 5. \\
\hline L.S.D & at 0.05 & N.S & N.S & 6.683 & N.S & & & $\mathbf{N}$ & \\
\hline \multicolumn{10}{|c|}{ Drip irrigation rates and cultivars. } \\
\hline \multirow{2}{*}{\multicolumn{2}{|c|}{$\begin{array}{l}\text { Water } \\
\text { quantity Cultivars } \\
\left(\mathrm{m}^{3} / \mathrm{fed} .\right)\end{array}$}} & \multicolumn{8}{|c|}{ Season } \\
\hline & & 2005 & 2006 & 2005 & 2006 & 2005 & 2006 & 2005 & 2006 \\
\hline \multirow{2}{*}{800} & Vic. & 6. & 5.800 & 3 & 40 & 47.30 & 33 & 4.736 & 4.799 \\
\hline & Lin. & 6.322 & 6.067 & 39.622 & 38.822 & 45.58 & 48.467 & 4.722 & 4.736 \\
\hline \multirow{2}{*}{1000} & Vic. & 6.2 & 5.578 & 40 & & & 02 & 5.125 & 5.092 \\
\hline & Lin & 6.533 & 6.078 & 41.844 & 35. & 47.50 & 49.611 & 4.822 & 5.040 \\
\hline \multirow{2}{*}{1200} & Vic. & 6.2 & 6.033 & 40. & 41 & 53.51 & 54 & 5.208 & 5.288 \\
\hline & Lin & 5.711 & 6.411 & 38.844 & 40.711 & 52.63 & 52.644 & + 5.152 & 5.130 \\
\hline \multicolumn{2}{|c|}{ L.S.D at 0.05} & N.S & N.S & N.S & N.S & N.S & N.S & N.S & N.S \\
\hline \multicolumn{10}{|c|}{ Sowing dates and cultivars. } \\
\hline \multirow{2}{*}{$\begin{array}{c}\text { Sowing } \\
\text { date }\end{array}$} & \multirow{2}{*}{ Cultivars } & \multicolumn{8}{|c|}{ Season } \\
\hline & & 2005 & 2006 & 2005 & 2006 & 2005 & 2006 & 2005 & 2006 \\
\hline \multirow{2}{*}{$20^{\text {th }}$ Sep. } & Vic. & 5.833 & 5.933 & 37.367 & 43.889 & 49.233 & 50.222 & 4.870 & 4.924 \\
\hline & Lin. & 6.111 & 6.300 & 37.644 & 40.822 & 47.944 & 49.544 & 4.854 & 4.860 \\
\hline \multirow{2}{*}{$10^{\text {th }}$ Oct } & Vic. & 6.600 & 5.644 & 39.289 & 38.833 & 52.344 & 56.644 & 5.167 & 5.255 \\
\hline & Lin & 6.389 & 6.278 & 41.000 & 37.644 & 50.522 & 53.589 & 5.100 & 5.156 \\
\hline \multirow{2}{*}{$1^{\text {st }}$ Nov. } & Vic. & 6.133 & 5.833 & 42.956 & 37.644 & 48.578 & 48.811 & 5.032 & 5.000 \\
\hline & Lin & 6.467 & 5.978 & 41.667 & 36.644 & 47.256 & 47.589 & 4.956 & 4.890 \\
\hline \multicolumn{2}{|c|}{ L.S.D at 0.05} & N.S & N.S & N.S & N.S & N.S & N.S & N.S & N.S \\
\hline
\end{tabular}

\begin{tabular}{|c|c|c|c|c|}
\hline \begin{tabular}{|c|} 
Characters \\
Treatments
\end{tabular} & $\begin{array}{c}\text { No. of } \\
\text { seeds/pod }\end{array}$ & $\begin{array}{l}\text { Wt. of } 100 \\
\text { seeds(gm) }\end{array}$ & Netting $\%$ & $\begin{array}{l}\text { Green pod } \\
\text { yield } \\
\text { tons/fed. }\end{array}$ \\
\hline
\end{tabular}




\begin{tabular}{|c|c|c|c|c|c|c|c|c|}
\hline \multirow{2}{*}{\begin{tabular}{|c|} 
Water \\
quantity \\
(m³/fed.)
\end{tabular}} & \multirow{2}{*}{$\begin{array}{c}\text { Sowing } \\
\text { date }\end{array}$} & \multirow{2}{*}{ cultivars } & \multicolumn{6}{|c|}{ Season } \\
\hline & & & 2005 & 2006 & 20052006 & 20052006 & 2005 & 2006 \\
\hline \multirow{6}{*}{800} & \multirow{2}{*}{$\begin{array}{l}20^{\text {th }} \\
\text { Sep. }\end{array}$} & Vic. & 5.667 & 5.800 & 38.20036 .867 & 46.70048 .400 & 4.602 & 4.692 \\
\hline & & Lin. & 6.533 & 6.000 & 37.00039 .7 & 45.40048 .200 & 4.638 & 4.620 \\
\hline & \multirow{2}{*}{$\begin{array}{l}10^{\text {th }} \\
\text { Oct. }\end{array}$} & Vic. & 5.967 & 5.867 & 40.26737 .300 & 48.60052 .233 & 4.866 & 4.929 \\
\hline & & Lin. & 6.200 & 6.400 & 42. & 46. & 4.812 & 4.860 \\
\hline & \multirow{2}{*}{$1^{\text {st }}$ Nov. } & Vic. & 5.500 & 5.733 & 38.73337 .6 & 46.60047 .967 & 4.740 & 4.776 \\
\hline & & Lin. & 6.667 & 5.800 & 39.53336 .6 & 44.76746 .867 & 4.716 & 4.728 \\
\hline \multirow{6}{*}{1000} & \multirow{2}{*}{$\begin{array}{l}20^{\text {th }} \\
\text { Sep. }\end{array}$} & Vic. & 5.733 & 5.867 & 36.26739 .467 & 48.33350 & 4.920 & 4.956 \\
\hline & & Lin. & 6.200 & 6.433 & 36.66737. & 47.20049 & 4.872 & 4.932 \\
\hline & \multirow[t]{2}{*}{ 10thOct } & Vic. & 7.300 & 5.500 & 38.60036 .9 & 51.30056 & 5.210 & 5.256 \\
\hline & & Lin. & 6.267 & 5.833 & 41.73 & 0 & 5.184 & 5.256 \\
\hline & \multirow{2}{*}{$1^{\text {st }}$ Nov. } & Vic. & 5.933 & 5.367 & 46.40037 .267 & 48.4004 & 5.244 & 5.064 \\
\hline & & Lin. & 6.300 & 5.967 & 47.13337. & 46.20047 & 5.052 & 4.932 \\
\hline \multirow{6}{*}{1200} & \multirow{2}{*}{$\begin{array}{l}20^{\text {th }} \\
\text { Sep. }\end{array}$} & Vic. & 6.100 & 6.133 & 37.63345 & 52.66751 & 5.088 & 5.124 \\
\hline & & Lin. & 5.600 & 6.467 & 39.26745 .3 & 51.23351 & 5.052 & 5.028 \\
\hline & \multirow{2}{*}{$\begin{array}{l}10^{\text {th }} \\
\text { Oct. }\end{array}$} & Vic. & 6.533 & 5.567 & 39.00042 .2 & 57.133 & 5.424 & 5.581 \\
\hline & & Lin. & 6.700 & 6.600 & 38.93340 .800 & 55.86758 .867 & 5.304 & 5.352 \\
\hline & \multirow{2}{*}{$1^{\text {st }}$ Nov. } & Vic. & 6.967 & 6.400 & 43.73338 .000 & 50.73349 .667 & 5.112 & 5.160 \\
\hline & & Lin. & 6.433 & 6.167 & 38.33336 .000 & 50.80048 .067 & 5.100 & 5.010 \\
\hline \multicolumn{2}{|c|}{ L.S.D at 0.05} & & N.S & N.S & N.S & N.S & N.S & N.S \\
\hline
\end{tabular}

Table (11): Effect of interaction among drip irrigation rates, sowing dates and cultivar on yield and its components during 2005Vic.: Victory freezer. 2006 and 2006-2007 seasons.

$$
\text { Lin.: Lincoln }
$$

\section{REFERENCES}

Abd-Alla, I.M., F.A. Abou Sedera, E.H. Abou El-Salehein and N.T. Mansour (2000). Physiological studies on pea. B- Effect of Rhizobium, Mycorrhyzae inoculation, nitrogen and phosphorus fertilizers on pea (Pisum sativum, L.) yield . J. Product. and Dev., 5 (1): 37-56

Abd El-Ati, Y. (2000). Growth and yield of cowpea as affected by irrigation regime, phosphorus application and VA-mycorrhizae infection treatments. Assiut J. of Agric. Sci. 31(2): 21-28.

Amer, A.H.; M. El-Desuki; O. M. Sawan and A.M. Ibrahim (2002b). Potentiality of some snap bean (Phaseolus vulgaris, L.) varieties under different irrigation levels at Shark El-Owinat region. Egypt. J. Appl. Sci., 17(1): 327-345.

Amer, A.H.; O. M. Sawan and S. R. Salman (2002a). Water requirements of snap bean (Phaseolus vulgaris, L.) as affected by sowing date under newly reclaimed soil at Shark El-Owinat region. J. Agric. Sci. Mansoura Univ., 27(9): 6097-6107.

El-Assiouty, F. M. M. (2004). Effect of some agricultural treatments on seed production and quality of cowpea. J. Agric. Sci. Mansoura Univ., 29(12): 7363-7384.

El-Gamiely, E. L.; H. M. Abd El-Naby ; Hala A. E. El-Sayed and A. E. Eata (1998). Effect of different planting dates and plant density on 1- 
Vegetative growth and leaf chemical composition of peas J. Agric. Sci. Mansoura Univ., 23 (1) 357-371.

El-Tantawy,E.M. and A.K. El-Beik (2007) Effect of irrigation intervals, organic manure rates and plant density on growth and yield of cowpea plant under north sinai conditions. Egy. J. Appl. Sci.,22 (1): 253-275.

Fisher, R.A. and R.M. Hogan (1965). Plant water relation, irrigation management and crop yield. Exp. Agric., 1: 161-177.

Gawish,R, A.. (1992). Effect of anti-transpirations application on snap bean (Phaseolus vulgaris, L.) growth under different irrigation regimes. Menofiya J. Agric. Res., 17(3): 1285-1308.

Hsiao, T. C. and E. Acevedo (1974). Plant response to water deficits, water use efficiency and drought resistance. Agric. Meteorology, 14: 59-84.

Ismail, T. B. A.(2000). Response of snap bean varieties to drip irrigation rates under sandy soil conditions. M. Sc. Thesis, Fac. Agric., Suez Canal Univ., Egypt.

Ismail, T. B. A. (2004). Effect of drip irrigation rates, organic fertilization and plant denesity on yield and quality of snap bean. Ph. D. Thesis, Fac. Agric., Suez Canal Univ., Egypt.

Jain, T.C. and D.K. Misra (1970). Effect of water stress on 1- Physiological activities of plants. Indian J. Agron., Vol. XV, 36-40.

Khalil, M. A. I. (1990) Evaluation of some cultivars under different planting dates Egypt. J. Appl. Sci., 5 (6) : 25 - 34

Mansour, N. T. S. (2006). Response of pea plants To biofertilization and plant density with different sowing dates under sandy soil conditions. Ph.D. Thesis,. Fac. of Agric. Suez Canal University.

Merghany, M.M. (1999). Response of snap bean to different rhizobium inculation methods and nitrogen levels under two drip irrigation regimes in new reclaimed sandy soil. Zagazig J. Agric. Res., 26 (4): 1091-1123.

Marschner, H. (1995). Mineral nutrition of higher plants (2 ed.) Academic Harcourt Brace and Company Puplisher New York, London, Tokyo 889.

Mohamed, F. I. and E. A. Y. El-Kabbany (1999). Studying the response of some new pea cultivars to NPK fertilization levels. Minufia. J. Agric. Res., 24 (3): 1047-1061.

Mohamed, F.I. and S.H. Qandil (1998).Effect of soil sulphur application on plant growth, yield componets and chemical constituents of pea cultivars . Egypt. J. Appl. Sci.,13 (4): 195-209.

Nour, E. M. E. (1999) Effect of some agricultural treatments on pea under sandy soil conditions . M. Sc. Thesis. Fac. of Agric. Zagazig Univ.

Nour, K. A. M. (2005). Response of some cowpea (vegna ungiculata, L.) cultivars to some irrigation levels by drip system and organic manure under sandy soil condition. Ph.D. Thesis,. Fac. of Agric. Mansuora Univ. 
Nour, K. A. M; T. B. Ali and Fayza M. A.Darwesh (2007). Water requirement of cowpea as affected by organic fertilization rates under newly reclimed soil conditions. Egypt. J. Appl. Sci.,22 (8B): 482-496.

Prasad, D.; K. M. Singh; R. N. Katiyar and R. N. Singh (1987). Influence of irrigation on the crop growth, pest incidence and crop yield of pea, (Pisum sativum,L.) Indian J. Ent. 49(3): 330-344.

Sangakara, U.R. (1990). Response of selected legume companion crops to irrigation frequencies. Agric. Water Mang., 17 :253-257.

Slatyer, R.O. (1969). Physiological significances of internal water relations to crop yield. Physiological aspects of crop yield, P. 53-88, Soc. Agron and Crop Sci., Madison, Wisconsin.

Shokr. M. M. B (2000).Response of pea (Pisum sativum, L) to planting dates and N P K fertilizing. Ph.D. Thesis,. Fac. of Agric. Mansuora Univ.

Streeter, J. G. (1993). Translocation, a key factor limiting the efficiency of nitrogen fixation in legume nodules. Physiol. Plant, 87, 616-623.

Todd, G. W. (1972). Water deficits and enzymatic activity. In Kozlowski, P. 117-216.

White, J. G.; G. W. Sheath and G. Meijer (1982). Yield of garden peas responses to variation in sowing rate and irrigation. New Zealand $\mathrm{J}$. Exp. Agric. 10: 155-160.

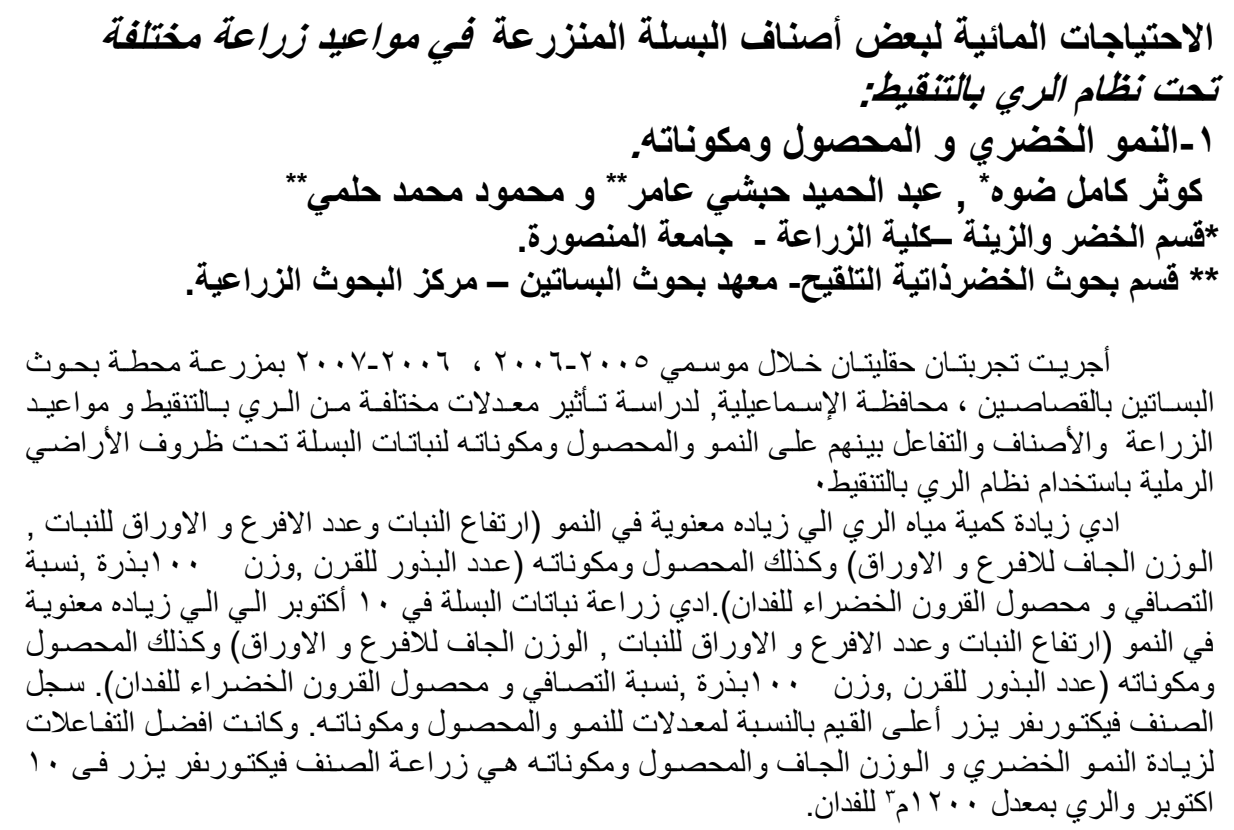

